\title{
Integration, productivity and technological spillovers: Evidence for Eurozone banking industries
}

\author{
Barbara Casu $^{\mathrm{a}}$, Alessandra Ferrari ${ }^{\mathrm{b}}$, Claudia Girardone $^{\mathrm{c}}$, John O.S. Wilson $^{\mathrm{d}}$
}

\begin{abstract}
In the context of the current debate on increased integration of eurozone banking markets following the global financial and sovereign debt crises, this paper evaluates the impact of regulatory reform, starting from the inception of the Single Market in 1992, on bank productivity and assesses the cross-border benefits of integration in terms of technological spillovers. We utilise a parametric meta-frontier Divisia index to estimate productivity change and identify technological gaps. We then assess the extent to which productivity converges within and across banking industries as a result of technological spillovers. Our results suggest that productivity growth has occurred for eurozone countries, driven by technological progress, both at the country and the supra-country level, although the latter slows or in some cases reverses since the onset of the crisis. Technological spillovers do exist, and have led to progression toward the best technology. However, convergence is not complete and significant long run differences in productivity persist. Improvements in technology are increasingly concentrated in fewer banking industries.
\end{abstract}

Keywords: Productivity Growth, Divisia Index, Spillovers, Convergence, European Banking.

\footnotetext{
${ }^{a}$ Cass Business School, City University London, EC1Y8TZ, UK. Email: b.casu@ city.ac.uk;

b Department of Economics, Whiteknights, University of Reading, Reading, RG6 6AA, UK. Email: a.ferrari@reading.ac.uk;

${ }^{c}$ Essex Business School, University of Essex, Colchester, CO4 3SQ, UK. Email: cgirardone@essex.ac.uk

$\mathrm{d}^{*}$ Corresponding Author. Centre for Responsible Banking \& Finance, School of Management, University of St Andrews, St Andrews, Scotland, KY16 9SS, UK. Email: jsw7@ st-andrews.ac.uk. Tel: +44 (0)1334462803 Fax +44 (0) 1334462812 Tel: +44 (0)1334462803 Fax +44 (0) 1334462812
} 


\section{Introduction}

This paper investigates productivity growth and convergence in eurozone banking industries since the onset of the EU single market project, which officially started with the signing of the Maastricht Treaty in 1992. The Treaty created the European Union (EU) and led to the establishment of the single currency in 1999. These regulatory changes were aimed at fostering integration by removing entry barriers and promoting competition, efficiency and productivity growth in the EU banking industry (Berger, 2003). The global financial crisis and subsequent sovereign debt crisis have severely impacted eurozone banks: many recorded large losses, which necessitated direct injections of government funding to support short term liquidity and solvency. Member states' actions designed to stabilise domestic banking sectors also led to a slowing down in the progress of EU integration (ECB, 2011, Goddard et al, 2015). This prompted the European Commission (EC) and European Parliament to re-design cooperation between national regulatory authorities and formalise arrangements for a Banking Union and a Capital Markets Union. ${ }^{1}$

Our paper not only traces the evolution of bank productivity over the long run, but is also one of the first studies to investigate the impact of the financial crisis and subsequent regulatory reforms on the productivity growth of eurozone banks. We frame our analysis within the context of technology spillovers, where spillovers are defined as the transfer of the best technology between banks and across borders. The evaluation of bank productivity growth is an essential component to the current debate on further eurozone integration (Giraleas et al., 2012). Until the start of the eurozone crisis, the benefits of financial integration were thought

\footnotetext{
${ }^{1}$ In response to the financial crisis, the EC pursued a number of initiatives to create a safer and sounder financial sector for the single market. These initiatives include stronger prudential requirements for banks, improved depositor protection and rules for managing and resolving failing banks. However, as the financial crisis evolved and turned into the sovereign debt crisis, it became apparent that for eurozone countries deeper integration was required. In September 2012, the EC put forward a roadmap for the creation of the Banking Union. By the end of 2014, member states agreed to establish a Single Supervisory Mechanism (SSM) and a Single Resolution Mechanism (SRM) for banks. Under the SSM the European Central Bank (ECB) has become the banking supervisor for all euro area banks. As part of an increased drive towards integration within the eurozone, in September 2015, the EC launched a plan for a Capital Markets Union with the aim of boosting business funding and investment financing, and enhancing economic growth.
} 
to outweigh potential costs. While there is a broad agreement in the academic literature that increased financial integration fosters the prospect of substantial gains, it is now apparent that there are also potential risks, evidenced by the propagation of economic shocks across borders.

In order to shed light on these issues and contribute to the current debate on further eurozone integration, we aim to answer the following questions: $(i)$ Is there evidence of sustained productivity growth in the eurozone banking markets since the introduction of the single market for financial services in 1992? (ii) What are the underlying mechanisms driving productivity growth? (iii) Did all banks in eurozone member states benefit equally from access to technology and any resultant technological spillovers? and (iv) To what extent does productivity converge within and across banking industries in the eurozone?

To answer these questions, we collect detailed information on commercial banks operating in eurozone countries over the period 1992 to 2014. By focusing on the euro area, our analysis allows us to assess whether the theoretical "level playing field" created by the single market and the introduction of the single currency enabled banks in different countries to access the same best available technology, or whether national borders continue to segment the technologies banks can access.

Our dataset spans the 23 years since the inception of the Single Market Programme in 1992. This relatively long time period is unique in the bank efficiency literature, with most prior studies covering a period of eight years. This time period provides us with a unique opportunity to examine the evolution of bank productivity during a time that encompasses significant regulatory reforms, before and after the banking crisis in the eurozone. The sample of banks used in this study is constructed carefully to account for entry, exit, M\&A activity, and changes in name and ownership. This is done by manually tracing the history of each individual bank. 
To evaluate productivity growth, we estimate a parametric eurozone-level meta-frontier based on stochastic country-specific efficiency frontiers (Battese et al., 2004; O'Donnell et al., 2008). This allows us make three methodological contributions to the literature. First, unlike most previous studies, we model efficiency and productivity in the context of a (bootstrapped) meta-frontier analysis, thus allowing for technological heterogeneity in a cross-country setting. Productivity change has been modelled in different ways, including the well-known Malmquist productivity index (Malmquist, 1953), which is applied by Caves et al. (1982) and extended by Fare et al. (1994). The Malmquist index has been used extensively in both parametric and nonparametric settings, including DEA-based Malmquist indices (see Giraleas et al., 2012 and Thanassoulis et al., 2015 for recent applications). We extend prior literature by estimating a Divisia index of total factor productivity (TFP) change and its components (Casu et al., 2013). Although used less frequently in the literature than the Malmquist index (Fethi and Pasiouras, 2010), the application of a Divisia index is appropriate for the estimation of translog cost functions, and it more easily allows for the separate effect of changes in environmental factors. In this context, our study contributes to the more recent literature that has explored the use of alternative specifications to the Malmquist index for the evaluation of productivity change (see, among others, Epure et al., 2011; Kerstens and Van de Woestyne, 2014). Our second innovative contribution relates the evaluation of changes in the meta-technology, where we estimate the Divisia index not only at the country level but also at the supra-country level. This approach is novel in the literature and allows us to compare the TFP changes in the meta-technology with the TFP changes at the country level to evaluate technological spill-overs over time. Our third contribution relates to our comprehensive convergence analysis. Departing from the extant literature on cross-country convergence which typically focuses on the convergence towards either an average technology or the technology of a representative country (despite ideally 
looking for a global technology), we evaluate convergence towards the meta-frontier. ${ }^{2}$ This approach is novel in the literature and it allows us to model convergence towards a global technology.

Our results show that banks in the eurozone experience productivity growth over the sample period. At the supra-country level, the introduction of the single currency in 1999 appears to have enhanced productivity, while the financial crisis appears to have resulted in the reverse. In terms of the drivers of productivity growth, it is improvements in technology which allow banks to deliver financial products and services more efficiently. Changes in technology before and after the introduction of the single currency have a positive impact on productivity, but this has slowed since the onset of the financial crisis. We also find evidence of technological spillovers, which transfer the best technology across borders. However, these spillovers are not complete and persistent differences in productivity remain across banking industries. Evidence suggests that improvements in technology are increasingly concentrated in fewer banking industries. Regulatory change and advances in technology appear to have led to increased differences in productivity between banks within the eurozone.

Overall, the present study provides new and extensive evidence on the evolution of bank productivity and the extent to which banks can achieve best practice technologies during a period of financial integration, financial crisis and resultant policy interventions. As such the results of the study are of relevance to ongoing policy developments across eurozone countries (including the establishment of a European Banking Union and European Capital Markets Union).

The remainder of the paper is structured as follows. Section 2 reviews the literature; Section 3 presents the dataset. Section 4 describes the methodology and the results of the

\footnotetext{
${ }^{2}$ Recent work by Horta and Camanho (2015) propose an alternative non-parametric methodology for the evaluation of convergence in an industry, considering a multi-input multi-output setting for the assessment of total factor productivity. In particular, the authors develop two new indexes to evaluate $\sigma$-convergence and $\beta$-convergence that can be computed using non-parametric techniques such as Data Envelopment Analysis (DEA).
} 
country-specific analysis of efficiency and TFP growth. The methodology and results of the meta-frontier and the cross-country TFP growth are reported in Section 5. Section 6 presents an analysis of convergence, while Section 7 concludes.

\section{Review of the literature}

There is a vast literature investigating bank efficiency and productivity, its components and its determinants using both parametric and non-parametric approaches. Berger and Humphrey (1997), Fethi and Pasiouras (2010) and Hughes and Mester (2015) provide comprehensive reviews of this literature. Most studies measure technical and cost efficiency

and, to a lesser extent, revenue and profit efficiency and productivity change. Despite the numerous studies, evidence regarding the efficiency and productivity of banks following an extended period of regulatory reforms is missing. In addition, there is a paucity of studies evaluating the impact of the financial crisis on bank efficiency and productivity indicating that there is a literature gap.

Earlier empirical evidence shows consistently that productivity growth has been slow in the US commercial banking industry during much of the 20th century (Humphrey, 1992, Bauer et al. 1993; Wheelock and Wilson, 1999; Stiroh, 2000; Alam, 2001; Berger and Mester, 2003; Tirtiroglu et al., 2005). A number of European studies have also addressed this issue, producing mixed empirical evidence (Altunbas et al., 1999; Battese et al., 2000). Casu et al. (2004) estimate productivity change in European banking during the 1990s to find that some countries benefited from productivity growth while others did not. Examples of mixed or unfavourable outcomes of deregulation were found in Portugal (Mendes and Rebelo, 1999; Canhoto and Dermine, 2003) and in Spain (Grifell-Tatje and Lovell, 1996; Lozano-Vivas, 1997; Kumbhakar et al., 2001). Outside the US and the EU, the impact of deregulation is 
sometimes found to be favourable to productivity growth, as in Australia (Avkiran, 2000; Sturm and Williams, 2004), Turkey (Isik and Hassan, 2003), Thailand (Leightner and Lovell, 1998), and Korea (Gilbert and Wilson, 1998).

A more recent strand of literature attempts to measure the extent of EU banking integration by exploring whether banking industries share a common cost or profit frontier. Notable examples include Bos and Schmiedel (2007) and Kontolaimou et al. (2012). The former applies a stochastic-frontier based meta-frontier model to evaluate cost and profit efficiency over the period 1993-2004. The authors evaluate the existence of a single market in terms of technology gap ratios. Their findings indicate a common technology, which is supportive of an integrated banking market. In contrast, Kontolaimou et al. (2012) follow a non-parametric meta-frontier framework and estimate DEA-based efficiency measures over 1997-2004. Based on the approach of Kounetas et al. (2009), the authors provide a decomposition of technology gaps. Their results suggest that European banks do not operate within an integrated banking market (in terms of a homogeneous production technology). Related literature explores the extent of banking integration via tests of convergence in efficiency and profitability of European banks. These studies find some evidence of convergence, but long run differences in profitability and efficiency (Casu and Girardone, 2010; Goddard et al., 2013).

In this paper, we augment the aforementioned literature to investigate one of the key mechanisms through which the potential benefits of increased integration should manifest, namely through productivity growth. Economic theory suggests that financial integration should stimulate productivity growth, via the general advancement of production technology and the efficiency improvements of individual firms. The extent to which empirical evidence supports these theoretical predictions is rather mixed. The controversy relates also to the sources of productivity growth (via the relative importance in technological progress, scale or 
efficiency improvements). Finally, there is still only limited cross-country empirical evidence on what type of regulatory and supervisory reforms can promote bank productivity growth, while ensuring financial sector stability (Barth et al., 2004; Delis et al., 2011; Ayadi et al., 2016).

\section{Data}

The sample used in the present study comprises commercial banks operating in eurozone countries over the period 1992 - 2014. Specifically, we focus on the countries adopting the single currency at its inception in 1999. We restrict our sample to commercial banks in order to minimise potential productivity differences arising from bank specialisation. The choice to focus only on commercial banks is supported by the extant literature (Bos and Schmiedel, 2007; Kontolaimou and Tsekouras, 2010). The data is collected from commercial banks' annual balance sheet and income statements made available via the Bankscope database. All banks are analysed individually to eliminate those institutions that operate as credit specialists, or which provide asset management and private banking services as their main activity. Given that we are interested in commercial banks engaged in comparable services across countries, we restrict our analysis to commercial banks with a loan to assets ratio greater than $10 \%$. Following standard practice, we revise our data for reporting errors, inconsistencies and missing values on relevant accounting variables (including assets, loans, other earning assets, deposits, equity, interest income and non-interest income). We have a relatively long time series compared to prior studies (1992 - 2014). This presents a number of challenges in creating consistent time series. ${ }^{3}$ To this end, we apply a number of filters to the sample,

\footnotetext{
${ }^{3}$ The definition of some of the variables of interest changes with the adoption of International Financial Reporting Standards (IFRS). Most banks in the sample ceased reporting using Generally Accepted Accounting Principles (GAAP) during the sample period. From January 1st, 2005, all EU listed banks were required to implement IFRS. Most large unlisted banks also switched to IFRS.
} 
following Kashyap and Stein (2000) and Cetorelli and Goldberg (2012).

The dataset is constructed carefully by tracing the bank history for each individual institution. We allow for entry, exit and M\&As over the sample period. Banks involved in M\&As during the sample period are treated as separate units prior to the merger, except in the calculation of the Divisia indices where values are summed for the year before the M\&A to make the calculation possible. Due to the limited number of observations remaining after applying these filters, we exclude banks located in Finland, Ireland and Luxembourg. This provides a maximum of 23 time-series observations on each bank. The final sample covers commercial banks operating in nine of the original eurozone countries (Austria, Belgium, France, Germany, Greece, Italy, Netherlands, Spain, and Portugal). The exception is Greece: due to the severity of the financial crisis, and subsequent bailouts and restructuring Greek banks are on a non-level playing field compared to the rest of the sample from 2009 onwards. For this reason, we drop Greek banks from the analysis after 2009. All data are converted into euro prior to 1999 and deflated using the domestic GDP deflator with 2005 as a base year. Table 1 presents the average value of the main variables of interest for all banks in our sample at the beginning of the sample period (1992); at the introduction of the single currency (1999); at the start of the financial crisis (2007); and at the end of the sample period (2014).

< Insert Table 1 near here>

As Table 1 shows, the average bank size has grown substantially over time, especially up to the financial crisis. Post-crisis, in some countries, average size increases. The increase in average size is undoubtedly a consequence of the process of consolidation, which has taken place over the sample period and translates in a general reduction in the number of banks over time (Goddard et al., 2015). Banks in all sample countries record similar equity-to-assets ratios. Cross-country differences become more apparent when considering the extent to which banks 
engage in traditional lending versus fee and trading-based activities. While the loan-to-asset ratio increases in most banking industries over the sample period (especially since 2000), the Italian, French, Spanish and Portuguese banks appear to specialise predominantly in lending activities. This is also reflected in lower levels of diversification, which display an overall decreasing trend over time, thus reinforcing the finding that asset growth in eurozone banking has been driven mainly by an increase in lending especially in Mediterranean countries.

\section{Country-specific efficiency, Total Factor Productivity and its decomposition}

In this section, we discuss the methodology and present the results of the empirical analysis of country-specific efficiency and Total Factor Productivity (TPF) change. This is justified given that the hypothesis of a common frontier that pools all the countries together is strongly rejected by the data on the basis an LR test for parameter stability (the null is rejected also when allowing for different country intercepts in the restricted model). The resultant analysis provides an overview of the main characteristics and changes for each banking industry in the sample. It is the first necessary step towards the estimation of the meta-frontierbased cross-country analysis, which is presented in Section 5.

The stochastic cost frontier is specified as a cost function with a composite error term made up of two separate, but jointly estimated, components of noise $v_{i t} \sim \mathrm{N}\left(0, \sigma^{2}\right)$ and inefficiency $u_{i t}$ (Aigner et al., 1977; Meeusen and Van den Broek, 1977). The performance of banks is evaluated in terms of their radial distance from the frontier, which arises solely from noise if they are perfectly efficient, and has a positive inefficiency component otherwise. Specifically, the efficiency of each bank is defined as $\mathrm{EFF}_{\mathrm{i}}=\exp \left(-\mathrm{u}_{\mathrm{i}}\right)$ : an efficient bank will sit on the cost frontier, with $\mathrm{u}_{\mathrm{i}}=0$ and thus $\mathrm{EFF}_{\mathrm{i}}=1$; an inefficient bank will be above the cost frontier, with $u_{i}>0$ and thus $\mathrm{EFF}_{\mathrm{i}}<1$. There are several possible theoretical distributions for 
the inefficiency component of the cost frontier. This study uses a parametric Likelihood Ratio

(LR) test to choose between nested models. The non-parametric Akaike criterion is used when models are non-nested. ${ }^{4}$ The flexible translog functional form for our model is as follows:

$$
\begin{aligned}
& \ln C_{i t}=\alpha_{0}+\sum_{m=1}^{2} \alpha_{m} \ln y_{m i t}+\sum_{j=1}^{2} \beta_{j} \ln w_{j i t}+\sum_{m=1}^{2} \sum_{q=1}^{2} \alpha_{m q} \ln y_{m i t} \ln y_{q i t}+ \\
& +\sum_{n=1}^{2} \sum_{j=1}^{2} \beta_{n j} \ln w_{n i t} \ln w_{j i t}+\sum_{j=1}^{2} \sum_{m=1}^{2} \gamma_{j m} \ln w_{j i t} \ln y_{m i t}+ \\
& +\lambda_{1} t+\lambda_{2} t^{2}+\sum_{m=1}^{2} \theta_{m} t \ln y_{m i t}+\sum_{j=1}^{2} \zeta_{j} t \ln w_{j i t}+e E U R+\sum_{m=1}^{2} e_{m} E U R \ln y_{m i t}+ \\
& +\sum_{j=1}^{2} e_{j} E U R \ln w_{j i t}+d_{c} D 07_{t} \sum_{m=1}^{2} d_{m} D 07 \ln y_{m i t}+ \\
& +\sum_{j=1}^{2} d_{j} E U R \ln w_{j i t}+\sum_{p}^{P} \eta_{p} E_{i t}+v_{i t}+u_{i t}
\end{aligned}
$$

In Equation (1), $C_{i t}$ is the observed total cost of bank $i$ at time $t$. To identify the input and output variables, we follow the intermediation approach (Sealey and Lindley, 1977). The two input prices are: the price of deposits $\left(w_{1}\right.$, interest expenses over customer and short-term funding); and the price of an aggregate input of labour, physical capital and other administrative costs ( $w_{2}$, personnel, total administrative and other expenses over total assets). The output variables are total loans $\left(y_{1}\right)$ and other earning assets $\left(y_{2}\right) .{ }^{5}$ The effect of the introduction of the single currency and the financial crisis are captured via the inclusion of dummy variables. The dummy EUR is a binary variable set equal to 1 for the period following the introduction of the single currency (1999-2014), and 0 for the period preceding it; and $t$ is a time trend. The dummy

\footnotetext{
${ }^{4}$ The most general distribution is a truncated normal with variable mean. This nests the truncated normal with constant mean, which nests the half normal. The alternative to these is the exponential, and that requires the use of the Akaike criterion. Kumbhakar and Lovell (2000) provide a detailed exposition of the frontier model.

${ }^{5}$ The output variable "other earning assets" is a summary variable which includes most non-lending activities that generate fee and commission income (including: loans and advances to banks; reverse repos and cash collateral; trading securities; derivatives; available for sale securities; held to maturity securities; other securities; investments in property; insurance assets and other earning assets). The variable does not include other OBS items (in the form of, for example, off-balance sheet exposure to securitisations, committed credit lines and other contingent liabilities). Given our long sample period and the need to build consistent time series of the relevant variables, we had to make a choice in term of inclusion/exclusion of particular OBS activities as a separate third output. While we are aware that large banks in most EU countries have broadened their portfolio to offer non-traditional services in recent years, the lack of the relevant data in the earlier years of the sample (particularly between 1992 and the mid-2000s) as well as the substantial cross-county differences lead us to exclude securitisation activities.
} 
D07 is a binary variable set equal to 1 for the period following the onset of the financial crisis (2007) onwards. All three are interacted with inputs and outputs to capture neutral and nonneutral technical change and technological progress.

$E$ denotes a set of bank-specific and country-specific control variables. The bankspecific variables are included to capture differences in size (fixed assets proxy the banks' branch network), risk (measured by the capital-to-assets ratio), and diversification, measured as:

$1-\left|\frac{\text { net loans }- \text { other earning assets }}{\text { total earning assets }}\right|$

Country-specific variables control for differences in macroeconomic activity (measured by GDP per capita), and for the structure of respective banking industries (proxied by the ratio of private credit granted by deposit money banks and other financial institutions to GDP).

There are different methods in the literature to calculate TFP growth, the choice generally depending on how the original production process has been estimated. Among the most popular ones are the Malmquist and the Divisia index. The Divisia is a continuous time index defined as the difference between the growth rates of outputs and inputs. It is an exact index for the translog production technology and in discrete time it corresponds to a Tornqvist index (Kumbhakar and Lovell, 2000; Hulten et al, 2001). Similarly the Malmquist, which is defined as the ratio of distance functions, corresponds to the ratio of Tornqvist indices if the production process is of the translog form and has constant second order coefficients. Both can be decomposed into the same components with the only difference that the Divisia allows more easily for the inclusion of environmental factors (Coelli et al 2005). The popularity of the Malmquist generally coincides with the use of non-parametric, DEA-type analyses which estimate the required distance functions (Fethi and Pasiouras, 2010). Divisia indexes instead 
offer a direct mapping with the estimated coefficients of cost and production functions, as in our case. This is therefore the method we use.

Following Kumbhakar and Lovell (2000), the Divisia index of TFP change for each of the $k$ countries is given by:

$$
\begin{aligned}
& \dot{T F P}=[1-\varepsilon(y, w, t, E ; \beta)] \dot{Y^{c}}-\dot{C}(y, w, t, E ; \beta)-\frac{\partial \ln C}{\partial E}+ \\
& +\sum_{j=1}^{J}\left[S_{j}-S_{j}(y, w, t, E ; \beta)\right] \dot{w_{j}}-\frac{\partial u}{\partial t}
\end{aligned}
$$

In Equation (2) $\varepsilon$ is total cost elasticity, a dual measure of returns to scale; $S_{j}$ and $S_{j}(y, w, t, E ; \beta)$ are respectively the actual and optimal input cost shares and finally $\dot{Y}^{c}$ is defined as

$$
\dot{Y^{c}}=\sum_{m=1}^{M}\left[\frac{\varepsilon_{m}(y, w, t ; \beta}{\varepsilon(y, w, t ; \beta}\right] \dot{y}_{m}
$$

As we can see from Equation (2), the Divisia index comprises five components. ${ }^{6}$ The first measures changes in the optimal scale of operation $(S C)$. The second captures technological progress, measured as shifts of the frontier over time (TC). The third measures the impact of the environmental variables $(E X)$. The fourth measures changes in allocative inefficiency, specified as a difference between the observed and the optimal inputs cost shares $(A L L C)$. Finally, the fifth component measures changes in cost efficiency $(E C)$. A positive value in each of these components translates into a positive growth in TFP. When reporting our results below, we transform the growth rate values of the Divisia index (which are positive or negative) into growth values which are larger or smaller than one. This is purely for presentational purposes. Equation (2) is first computed for each country using the country-

\footnotetext{
${ }^{6}$ The $\cdot$ over a variable denotes its rate of change. Equation (2) is calculated for each year-pair in each country, and averaged across all the banks. Kumbhakar and Lovell (2000) provide an extended discussion of this model and its components.
} 
specific parameter estimates derived from Equation (1), and then for the whole sample on the basis of the estimates of the meta-frontier. This approach is novel as it allows the direct evaluation of TFP changes on the meta-technology and a more direct comparison with the country based frontiers.

In Equation (1) inefficiency $u_{i t}$ is independent of the error $v_{i t}$ and the regressors. The preferred distribution for inefficiency in the current study is the exponential, with additional heterogeneity entering in the form of heteroscedasticity. The model is estimated by Maximum Likelihood (ML), with linear homogeneity in input prices and Young's symmetry imposed prior to estimation. The results indicate that the cost function is always consistent with its theoretical properties. A summary of the main results is presented in Table 2. Inputs and outputs point elasticities have the expected sign. Inefficiency is always statistically significant (except for Belgium). Increases in diversification appear to reduce costs significantly, as do increases in the equity to assets ratio. Increases in the level of fixed assets, as expected, increase costs. The introduction of the single currency usually leads to a reduction in banks' total costs (negative intercept dummy), although not always significantly so, and virtually in all cases it also provokes a change in production technology (significant interaction dummies). Finally, the dummy variable D07 is in most cases positive and significant, implying that the financial crisis led to an increase in bank costs, although it does not affect the production technology of all countries (it is significant only in 4 of the 9 countries).

\section{<Insert Table 2 near here>}

Turning to efficiency, the results indicate that levels are generally high and changes, both positive and negative, are quite contained. More pronounced reductions characterise the period following the financial crisis, as one would expect. Changes in efficiency over time can often be the result of technological improvements, which shift the frontier making it more 
difficult for banks to reach it. This is illustrated by the results of the estimation of the Divisia index, which are presented in Table 3 . Table 3 also presents the results of the TFP index and its components for the entire sample period from 1992 to 2014, and for the two sub-periods before and after 1999. In order to illustrate any possible effects of the financial crisis, we also present separately the results for the 2007 to 2014 period. The superscript $k$ is used to distinguish these results from those based on the meta-frontier estimated in Section 5.

\section{<Insert Table 3 near here>}

The results indicate that all banking industries experience overall increases in $\mathrm{TFP}^{\mathrm{k}}$ between 1992 and 2014. The yearly improvements range from $0.1 \%$ in Austria to $1.7 \%$ in Portugal. In most cases these improvements continue at a slower pace after the introduction of the single currency. Technical change $\left(\mathrm{TC}^{\mathrm{k}}\right)$ contributes positively to this growth in all countries across the whole time period. Among the most plausible reasons for these positive shifts in the production frontiers is the extent of technological advances and automation that transformed the processing and analysis of financial data during the sample period, as well as delivery systems used to distribute financial products and services to bank customers (Goddard et al., 2010, 2015). Changes in scale efficiency $\left(\mathrm{SC}^{\mathrm{k}}\right)$ are also positive across the sample, changes in cost efficiency $\left(\mathrm{EC}^{\mathrm{k}}\right)$ are generally small, as explained before, while those in allocative efficiency $\left(\mathrm{ALLC}^{\mathrm{k}}\right)$ are varied and often negative.

\section{Total Factor Productivity and technology gaps: a meta-frontier analysis}

The estimation of a meta-frontier is a useful way to address the problem of technological heterogeneity across the $k$ countries. The rationale underlying the meta-frontier 
is that the $k$ different technologies belong to a common meta-technology set to which each banking industry has potential access (Battese et al., 2004). In other words, the meta-frontier allows for the possibility of technological spillovers between banks. The meta-frontier is defined as the boundary of this meta-technology set and is estimated as the envelope of the single-country stochastic frontiers (estimated previously). If the country-specific frontiers are given by:

$$
C_{i t}^{k}=f\left(X_{i t} \beta^{k}\right) \exp \left(v_{i t}^{k}+u_{i t}^{k}\right)=\exp \left(X_{i t} \beta^{k}\right) \exp \left(v_{i t}^{k}+u_{i t}^{k}\right)
$$

with country specific parameters $\beta^{k}$, the meta-frontier can be written as

$$
C_{i t}^{*}=f\left(X_{i t} \beta^{*}\right)=\exp \left(X_{i t} \beta^{*}\right)
$$

Equation (4) envelopes the $k$ estimations of Equation (3) using the same functional form to derive a set of parameters $\beta^{*}$ such that the meta-technology has the minimum possible cost, i.e.:

$$
X_{i t} \beta^{*} \leq X_{i t} \beta^{k}
$$

The meta-frontier is estimated by linear programming, hence solving:

$\operatorname{Min} L=\sum_{i=1}^{N} \sum_{t=1}^{T}\left(X_{i t} \beta^{k}-X_{i t} \beta^{*}\right)$

subject to Equation (5). Given the deterministic nature of this approach, we use a bootstrap procedure to test the significance of the estimated coefficients. ${ }^{7}$ Once the meta-frontier is

\footnotetext{
${ }^{7}$ The bootstrap algorithm is based on Efron and Tibshirani (1998). We estimate (6) subject to (5) over 1,000 iterations using random sampling with replacement, and compute the $95 \%$ confidence intervals using the percentile method with and without bias correction. In order to conserve space and remain consistent with the country analysis, we do not report the detailed results (as they are only relevant indirectly to the analysis).
} 
estimated, the distance of each bank from it defines its meta-efficiency score (EFF*). ${ }^{8}$ This comprises two parts: the banking industry country-specific efficiency and the technological gap ratio (TGR):

$$
E F F_{i t}^{*}=\exp \left(-u_{i t}^{k}\right) \frac{\exp \left(X_{i t} \beta^{*}\right)}{\exp \left(X_{i t} \beta^{k}\right)}
$$

The TGR measures the distance between the country frontier and the meta-frontier. TGR values range from zero to one; higher values indicate a closer proximity to the metafrontier (i.e. to the best possible technology) and vice versa. ${ }^{9}$ TGR values are used to identify the technology leaders of a given banking industry. Differences between countries imply the existence of technology gaps.

As in the case of the single countries analysis, we use the meta-frontier estimates to compute Divisia indices of TFP. The results are reported in Table 4, which shows the average country estimates of the meta-frontier Divisia index (TFP*) along with its five components at different points in time. The TGRs and the efficiency scores are reported in Table 5.

We find clear evidence of TFP* growth over the whole sample period for all banking industries. This growth is generally sustained; it is faster after the introduction of the single currency and it slows down following the financial crisis, in some cases becoming negative. The overall improvement in TFP* is driven primarily by technological change (TC*) which is sizeable and continues to improve for all countries both before and after the introduction of the single currency. Scale, allocative and cost efficiency have smaller, often negative patterns. Overall, the results suggest that the meta-technology is improving over time causing

\footnotetext{
${ }^{8}$ In what follows we use the superscript $*$ to indicate results from the meta-frontier as opposed to those derived from estimating individual country frontiers, where we use the superscript $k$.

${ }^{9}$ For example, a TGR value of 0.8 for bank $i$ implies that even if bank $i$ were operating on the national best practice frontier (i.e. it is fully efficient), it could potentially cut its costs by 20 per cent if it adopted the best meta-technology. On the other hand, a TGR value of 1 indicates that the bank is using the best technology although not necessarily in the most efficient manner.
} 
adjustments in the efficiency with which banks in different countries perform their activity. The analysis of the TGR and convergence (discussed below) clarify how banking industries in eurozone countries compare in this respect.

\section{$<$ Insert Table 4 around here>}

\section{$<$ Insert Table 5 around here>}

Table 5 reports average TGR values across all banks in each country before and after the introduction of the single currency, as well as overall. With the exception of Italy and Greece, all banking industries show a reduction in TGR values following the introduction of the euro, a trend that continues after the financial crisis. This result implies that, over time, the average bank is slipping further away from the best available technology. This suggests that the continued technical improvements found by the Divisia index must be led by a small number of banks, or by some banking industries. These "technology leaders" are contributing to the best available technology while other banks lag behind. It is therefore interesting to carry out an analysis of these technology leaders, as we do below.

First of all, as showed in Table 5, the Dutch banking system displays the lowest TGRs and the Italian banking system the highest. Italian banks appear to score better than banks in other countries, with TGRs higher than 0.9 , both before and after the introduction of the single currency. This implies that Italian banks contribute to the meta-frontier (using the best technology available) more than others. It is not unusual for Italian banks to score well in terms of relative productivity levels (Casu et al., 2004; Fiorentino et al., 2009). These results also are consistent with Kontolaimou et al (2012) who argue that this is the result of a very small number of Dutch banks (and a high number of Italian banks) on the meta-frontier. The authors attribute this result to output-invariant efficiency and suggest that the Dutch and other laggard 
banking systems have developed strong and rigid routines that are extremely efficient in their home markets but prevent them from operating on the meta-frontier.

To gain a clearer understanding of the changes described above, we analyse the characteristics of the technology leaders in the sample. These can be defined very restrictively as the banks with a TGR $\geq 0.99$, or using a more generous threshold of $0.95 .{ }^{10}$ The results are consistent and indicate that there are relatively few technical leaders in the sample (in total they are just under $2 \%$ and $10 \%$ respectively, depending on the threshold definition). Their number increases quite steadily until 1998 then drops substantially immediately after the introduction of the euro, suggesting that the change in the macroeconomic environment brings some adjustments to banks' technology. The number of technology leaders start increasing again in the mid-2000s but is soon affected by the financial crisis of 2007 and by the sovereign debt crisis in 2011. Signs of recovery could be inferred from the increase in 2014 , but this is only one data point. While leaders are more evenly distributed (between Austria, Germany and Italy) before the introduction of the single currency, Italian banks completely dominate the sample afterwards, with a staggering $88 \%$ of technical leaders. German and French banks come next but at great distance with $5 \%$ and $3.5 \%$ respectively. Summary results of these changes are presented in Table 6.

$<$ Insert Table 6 around here>

The aforementioned results are consistent with our intuition that improvements do take place, but are concentrated within fewer banking industries. To corroborate this interpretation, we perform a Spearman rank correlation test to see if TGR rankings have changed significantly since the introduction of the euro. The estimated coefficient is 0.58 and the null of

\footnotetext{
${ }^{10}$ Given the deterministic nature of the meta-frontier, a threshold of 1 would reduce the number of relevant observations too much to offer any useful insight.
} 
independence between the two series is rejected (p-value of 0.00). As it well known, from a statistical point of view rejecting a null is not the same as accepting a specific alternative. The problem with this type of routine test is that the hypothesis we are interested in is not whether the two series are independent $\left(\mathrm{H}_{0}: \rho=0\right.$, this is the test of significance automatically carried out by all software), but the much more restrictive one of whether they have remained the same $\left(\mathrm{H}_{0}: \rho=1\right)$. Since the value of 1 lies on the boundary of the parameter space, this poses difficulty in the formulation of the test. We therefore follow Bonett and Wright (2000) and construct a confidence interval to establish where the true population correlation coefficient lies. The $95 \%$ and $99 \%$ confidence intervals are 0.53 and 0.78 , and 0.49 and 0.82 respectively. This indicates that while the series are not independent (the lower threshold is larger than 0), the upper threshold is far below the value of 1 . This suggests that while more technically advanced banks tend to remain so (and vice versa), their rankings are far from identical in the two sub-periods. In other words, we can conclude that a significant reordering has taken place. These results are reported in the bottom panel of Table 6 . As a consequence, it appears that the regulatory effort towards integration may have led to increased differences between banks within the eurozone, particularly since 1999.

\section{Technical change, efficiency change and convergence}

In this section we assess whether the banking industries in the sample converge toward the same efficiency and technology. There are several approaches in the literature to the measurement of convergence. Given our research questions, and to carry out the most comprehensive analysis, we follow an established econometric literature that comprises cross sectional and time series approaches (Bernard and Durlauf, 1996; Islam, 2003; Bartlesman et al., 2008). The first approach we use is based on the time series properties of the data and 
examines whether there is a catch-up process toward the meta-frontier. The data is observed at the country level and the results will indicate whether (some or all) countries are moving towards the meta-technology. As discussed in the introduction the analysis of convergence towards a global technology is new in the literature as previous cross-country work analysed convergence towards an average technology. To do this we calculate a catch-up $(C U)$ index to measure the speed at which banking industries catch up to the best technology (Chen and Yang, 2011). We then test for convergence towards this best technology by means of panel unit root tests. This is augmented with a second approach which tests specifically for the existence of $\beta$ and $\sigma$-convergence in the measures of performance, thus focusing on the cross sectional characteristics of the sample at the bank level.

\subsection{Catch-up index and panel unit root tests}

The $C U$ index is defined as the ratio of the technical change of the meta-frontier to that of the country frontier; averaging across banks for each country $k$ at time $t$ (i.e. between $t$ and $t$-1) this is defined as:

$$
C U_{k t}=\frac{T C_{k t}^{*}}{T C_{k t}}
$$

The catch-up index provides an indication of the difference in the speed of convergence towards the meta-frontier between banking industries and over time. Lower values of $C U$ indicate a faster speed of convergence, and vice versa. The existence of a process of convergence towards the meta-frontier can be formally tested with unit root tests, such as the Dickey Fuller (D-F). If performed at the individual country level, the D-F test has low power, a problem that can be partly obviated by using panel unit root tests. This is therefore the approach we follow.

If the data generating process is given by: 


$$
\ln T C_{k t}=\gamma^{k}+\lambda \ln \left(\frac{T C_{k, t-1}^{*}}{T C_{k, t-1}}\right)+\ln T C_{k, t-1}+\varepsilon_{k t}
$$

and

$$
\ln T C^{*}{ }_{k t}=\gamma^{*}+\ln T C_{k, t-1}^{*}+\eta_{k t}
$$

Then combining (9) and (10) we get:

$$
\ln \left(\frac{T C_{k t}}{T C_{k t}^{*}}\right)=\gamma+(1-\lambda) \ln \left(\frac{T C_{k, t-1}}{T C_{k, t-1}^{*}}\right)+\phi_{k t}
$$

where $\gamma=\left(\gamma^{\mathrm{k}}-\gamma^{*}\right)$. The presence of a unit root in (11) would be indicative of no technical spillovers between the meta-frontier and the national frontiers, i.e. no catching up and no convergence toward the best technology. Convergence is found instead if $\lambda>0$. Equation (11) can be specified to accommodate for additional regressors, such as lagged terms of the dependent variable, country-specific intercepts and/or different convergence parameters.

There are several panel unit root tests available. These vary depending on: the relative size and asymptotic properties of the cross sectional and time dimensions; the null and alternative hypotheses; and the assumptions made about cross sectional differences. We choose to perform three different tests, which are complementary in the way in which they test for the presence of a unit root in the series, and hence for convergence. All tests are suitable for the case where $\mathrm{T}>\mathrm{N} .{ }^{11}$ The first two are the Levin-Lin-Chu (LLC) test (2002) and a Fisher-type test following Choi (2001), which consist of a combination of p-values from various unit root tests. Both tests share the same null hypothesis of non- stationarity but formulate different alternatives, thus making it possible to be more precise as of the nature of the convergence

\footnotetext{
${ }^{11}$ Recall that in this case the panel is defined as $\mathrm{k}$ countries observed over a period of $\mathrm{T}$ years.
} 
process. In particular, the alternative in the Fisher type test allows for different autoregressive coefficients, while in the Levin-Lin-Chu test the alternative is more restrictive and requires that all series share the same autoregressive coefficient. ${ }^{12}$ Finally the Hadri LM test (2000) operates under the null hypothesis of (trend) stationarity against the alternative that some of the panels have a unit root. ${ }^{13}$ Since in any statistical test the null is true unless there is sufficiently compelling evidence to suggest the contrary, it is very informative to reverse it to check for consistency. The results are reported in Tables 7 and 8 .

\section{<Insert Table 7 around here>}

Table 7 reports the catch up index of each banking industry in different time periods. All countries show an increase in the catch-up index after 1999 (column $a$ vs column $c$ ), with the exception of Greece. This indicates a progressive decrease in the speed of convergence after the introduction of the single currency, consistently with the results from the Divisia index and the TGR analysis: technical change on the meta-frontier continues to take place but with fewer countries contributing to it. Despite some occasional minor improvements in the mid2000s, the speed of convergence continues to decrease with the financial crisis. This corresponds to recent evidence that suggests that integration of the EU banking industry has declined since the onset of the financial crisis (ECB, 2011, 2012, 2015a, b). In terms of crosscountry banking industry comparisons, Italy stands out again, with the lowest catch-up index both before and after the introduction of the single currency. This is not surprising given the Italian banking industry exhibits the highest average TGR values, and the largest number of banks defining the meta-frontier.

\footnotetext{
12 While strongly rejecting the null in the LLC would be a very definite result, not rejecting it for instance at the $5 \%$ level still allows for convergence of the Fisher-type. However, this test in isolation could not indicate whether identical patterns exist. ${ }^{13}$ The unit root equation in the Hadri test has a different formulation, but the intuition is the same as in the other tests. As a consequence, we omit further details.
} 
Table 8 reports the results of the panel unit root tests. In all specifications we allow for country fixed effects; when possible we also do not include a time trend, as this would lower the power of the tests (Baltagi, 2008). The null hypothesis of non-stationarity is rejected both in the LLC and the Fisher-type tests (more strongly in the latter than in the former) suggesting that a process of convergence towards the meta-frontier could be taking place. Rejection of the null does not necessarily indicate that all the panels are stationary, and this is confirmed by the Hadri test which rejects the hypothesis of stationarity for the whole panel in favour of stationarity for some of the countries only. Overall, these results suggest that a process of convergence is taking place, but is not shared by all banking industries in the sample, consistently with the simple $C U$ analysis of the previous section.

<Insert Table 8 around here>

Finally, we estimate Augmented Dickey Fuller (ADF) tests on Equation (11) for each banking industry in our sample. In this case the null is that of a unit root indicated by an insignificant $\lambda$, with full convergence given by an insignificant intercept. The results are reported in Table 9, and are generally consistent with the above interpretation.

<Insert Table 9 around here>

\section{$6.2 \beta$ and $\sigma$-convergence}

We next examine the cross sectional characteristics of the panel data set at the bank level. We test for the existence of $\beta$ convergence in the levels of cost efficiency, meta-efficiency and TGR, both in the long run (before and after the introduction of the single currency) and in the short run (year-by-year) for the whole panel. Specifically, if $P_{k i t}$ is the measure of performance under consideration for bank $i$ at time $t$ in country $k$ the tests for long run 
(superscript $l$ ) and short run (superscript $s$ ) convergence are performed respectively as follows (Fung, 2006):

$$
\begin{aligned}
& \ln P 2_{k i}-\ln P 1_{k i}=\gamma_{0}^{l}+\lambda^{l} \ln P 1_{k i}+\gamma_{k}^{l} X_{k i}+\varepsilon_{k i} \\
& \ln P_{k i t}-\ln P_{k i, t-1}=\gamma_{0}^{s}+\lambda^{s} \ln P_{k i, t-1}+\gamma_{k}^{s} X_{k i}+\varepsilon_{k i t}
\end{aligned}
$$

In Equation (12) P1 and P2 are the efficiency (or meta-efficiency or TGR) levels of bank $i$ in country $k$ in the long run, that is at the beginning and at the end of the sample period (1992 and 2014). $X$ is a vector of country dummies whose significance indicates that countries are moving towards separate steady-state productivity levels (conditional convergence). In both equations, absolute $\beta$-convergence is found if $\lambda<0$ and $\gamma_{k}=0$, and conditional $\beta$ convergence is found if $\lambda<0$ and $\gamma_{k}$ is $\neq 0 . \beta$-convergence is thus defined as a significant negative correlation between the level of efficiency and its growth rate. The speed of adjustment is measured by $\lambda$ with half-life measured as $\ln (0.5) / \ln (1+\lambda)$. If this negative correlation is due to convergence and not simply to a process of mean-reversion, then $\sigma$ convergence must also be present, implying a significant reduction in the dispersion levels of efficiency between countries over time. More specifically, and with reference to equation (12), if $\sigma_{1}^{2}=\operatorname{var}\left(\ln P 1_{i k}\right)$ and $\sigma_{2}^{2}=\operatorname{var}\left(\ln P 2_{i k}\right)$ the existence of $\sigma$-convergence implies that the ratio $\sigma_{1}^{2} / \sigma_{2}^{2}>1$. Following Lichtenberg (1994) this ratio is equivalent to the following test statistic which follows an F distribution:

$$
\frac{\sigma_{1}^{2}}{\sigma_{2}^{2}}=c=\frac{R^{2}}{(1+\lambda)^{2}} \sim F_{N-q}^{N-q}
$$

where $R^{2}, \lambda$ and $q$ all refer to the estimation of Equation (12). The null hypothesis $c=1$ means no $\sigma$-convergence; therefore rejecting the null implies the existence of $\sigma$ convergence and vice versa. However, as observed by Carree and Klomp (1997), the above is true only if $\sigma_{1}^{2}$ and $\sigma_{2}^{2}$ 
are independent. This assumption is tenable in large samples and the test statistic needs however to be adjusted as

$$
c^{*}=\frac{c-(1+\lambda)^{2}}{(1+\lambda)^{2}} \sim F_{N-q-1}^{N-q}
$$

This is the specification that we use in this paper. The results are presented in Table 10 and indicate the existence of conditional $\beta$-convergence both in the long and the short run, confirmed by $\sigma$-convergence and across all three performance measures (cost efficiency, metaefficiency and TGR). The results of the short run analysis (which tracks changes on a year-byyear basis), suggest a rapid speed of convergence in cost efficiency (of 33.2\% per year, corresponding to a half-life of 1.7 years) consistently with the generally high average levels found in the sample. The convergence rate for meta-efficiency and TGR is of $8 \%$ per year in each case, corresponding to a much longer half-life of about 8 years. In other words while banking industries within the eurozone are relatively close to their steady state in cost efficiency, they require longer to reach steady state in TGR, and thus overall meta-efficiency. Furthermore, the significance of the dummy variables suggests that there are long run differences across countries. As a robustness check we have also re-estimated Equations (12) - (15) using the performance measures in levels rather than logs. The results are the same and confirm the existence of conditional $\beta$ and $\sigma$ convergence in the levels as well as in the growth rate of the various performance measures.

Overall the results imply that technological spillovers between banking industries do exist. Banks not only move progressively toward full efficiency, but also toward the use of the best technology, albeit the latter takes place more slowly than the former. All tests suggest that banking industries converge toward their own steady state level of productivity.

< Insert Table 10 around here> 


\section{Final Remarks}

This study evaluates productivity change in eurozone banking markets since the creation of a single market for financial services in 1992. In addition, the analysis aims to uncover the underlying mechanisms driving productivity growth, and explore the extent to which bank productivity converges.

The econometric analysis comprises the estimation of a parametric meta-frontier TFP Divisia index to measure productivity change, and a series of convergence tests to assess whether banking industries in different countries are moving towards the best available technology and efficiency. Our results suggest that productivity growth has occurred in eurozone banking industries, driven by continued technological improvements. We also find that banking industries within the eurozone converge toward the best available technology, albeit with decreasing speed over time. Technological spillovers between different eurozone banking industries exist, and have led to progression toward the best technology. However, convergence is not complete, and significant long run differences between eurozone banking industries persist. Improvements in technology are increasingly concentrated in fewer banking industries. The trends uncovered in our study appear to indicate that (similarly to other knowledge intensive industries), there is a tendency toward geographical concentration rather than integration. In order to provide policy makers with useful insights concerning the dynamics of the single market for financial services, further research could focus on analysing the underlying mechanisms leading to the persistence of technological gaps.

Overall, the results of our analysis are particularly relevant to EU policymakers, in light of recent initiatives to increase integration in the eurozone following the risk of fragmentation brought about by the financial and sovereign debt crisis. 


\section{References}

Aigner, D., Lovell, C.A.K., Schmidt, P., 1977. Formulation and estimation of stochastic frontier production models. Journal of Econometrics, 6, 21-37.

Alam, I. M. S., 2001. A nonparametric approach for assessing productivity dynamics of large US banks. Journal of Money, Credit, and Banking, 33, 121-139.

Altunbas, Y., Goddard, J., Molyneux, P., 1999. Technical change in banking. Economics Letters, 64, 215-221.

Avkiran, N.K., 2000. Rising productivity of Australian trading banks under deregulation 19861995. Journal of Economics and Finance, 24, 122-140

Ayadi, R., Ben Naceur, S., Casu B., Quinn, B., 2016. Does Basel compliance matter for bank performance? Journal of Financial Stability, 23, 15-32.

Baltagi, B., 2008. Econometric Analysis of Panel data. John Wiley \& Sons, New York.

Bartlemans, E., Haskell, J., Martin, R., 2008. Distance to which frontier? Evidence on productivity convergence from international firm-level, Centre for Economic Policy Research Paper Number DP7032.

Barth, J. Caprio, G., Levine, R., 2004. Bank regulation and supervision: What works best? Journal of Financial Intermediation, 13, 205-248.

Battese, G.E., Heshmati, A., Hjalmarsson, L., 2000. Efficiency of labour use in the Swedish banking industry: A stochastic frontier approach. Empirical Economics, 25, 623-640.

Battese, G.E., Rao, D.S.P., O’ Donnell, C.J., 2004. A meta-frontier production functions for estimation of technical efficiencies and technology gaps for firms operating under different technologies. Journal of Productivity Analysis, 21, 91-103.

Bauer P.W., Berger A.N., Humphrey, D.B., 1993. Efficiency and productivity growth in U.S. banking. In Fried H.O., Lovell C.A.K., Schmidt, S.S. (Eds.) The Measurement of Productive Efficiency: Techniques and Applications Oxford University Press, Oxford. 
Bernard, B., Durlauf, S., 1996. Interpreting tests of the convergence hypothesis. Journal of Econometrics, 71, 161-173.

Berger, A.N., 2003. The efficiency effects of a single market for financial services in Europe. European Journal of Operational Research, 150, 466-481.

Berger, A.N., Humphrey, D.B., 1997. Efficiency of financial institutions: international survey and directions for future research. European Journal of Operational Research, 98, 175212.

Berger, A.N., Mester, L.J., 2003. Explaining the dramatic changes in performance of U.S. banks: technical change, deregulation, and dynamic changes in competition. Journal of Financial Intermediation, 12, 57-95.

Bonett, D.G., Wright, T. A., 2000. Sample size requirements for estimating Pearson, Kendall and Spearman correlations. Psychometrika, 65, 23-28.

Bos, J.W.B., Schmiedel, H., 2007. Is there a single frontier in a single European banking market? Journal of Banking \& Finance, 31, 2081-2102.

Canhoto, A. and Dermine J., 2003. A note on banking efficiency in Portugal: New versus old banks. Journal of Banking \& Finance, 27, 2087-2098.

Carree, M.A., Klomp L., 1997. Testing the convergence hypothesis: A comment. Review of Economics and Statistics, 79, 683-686.

Casu, B., Girardone, C., Molyneux, P., 2004. Productivity change in European banking: A comparison of parametric and non-parametric approaches. Journal of Banking \& Finance, 28, 2521-2540.

Casu, B., Girardone, C., 2010. Integration and efficiency convergence in EU banking markets. Omega, 38, 260-267.

Casu B, Ferrari, A., Zhao, T., 2013. Regulatory reform and productivity change in Indian banking. Review of Economics and Statistics, 95, 1066-1077. 
Caves, D., Cristensen, L., Diewert, W. E., 1982. The economic theory of index numbers and the measurement of input, output and productivity. Econometrica, 50, 1393-1414.

Cetorelli, N., Goldberg, L.S., 2012. Banking globalization and monetary transmission. Journal of Finance, 67, 1811-1843.

Chen, K.H., Yang, H.Y., 2011. A cross-country comparison of productivity growth using a generalized meta-frontier Malmquist productivity index: With application to banking industries in Taiwan and China. Journal of Productivity Analysis, 35, 197-212.

Choi I., 2001. Unit root tests for panel data. Journal of International Money and Finance, 20, 249-272.

Coelli, T.J, Rao, D., O'Donnell, C.J, Battese, G.E., 2005. An Introduction to Efficiency and Productivity Analysis, $2^{\mathrm{ND}}$ Edition. Springer, New York.

Delis, M. D., Molyneux P., Pasiouras F., 2011. Regulations and productivity growth in banking: evidence from transition economies. Journal of Money, Credit and Banking, $43,735-764$.

ECB., 2011. Financial Integration in Europe. European Central Bank, Frankfurt.

ECB., 2012. Financial Integration in Europe. European Central Bank, Frankfurt.

ECB, 2015(a) Financial Integration in Europe. Frankfurt: European Central Bank.

ECB, 2015(b) Report on Financial Structures Frankfurt: European Central Bank.

Efron, B. and Tibshirani, R.J., 1998. An Introduction to the Bootstrap. Chapman and Hall, Boca Raton.

Epure, M., Kerstens, K., Prior, D., 2011. Bank productivity and performance groups: A decomposition approach based upon the Luenberger productivity indicator. European Journal of Operational Research, 211, 630-641. 
Färe, R., Grosskopf, S., Norris, M., Zhang, Z., 1994. Productivity growth, technical progress and efficiency change in industrialized countries. American Economic Review, 84, 6683.

Fethi, M. D., Pasiouras, F., 2010. Assessing bank efficiency and performance with operational research and artificial intelligence techniques: A survey. European Journal of Operational Research, 204, 189-198.

Fiorentino E., De Vincenzo A., Heid, F., Karmann A., Koetter M., 2009. The effects of privatization and consolidation on bank productivity: Comparative evidence from Italy and Germany. Deutsche Bundesbank Discussion Paper Number 03/2009.

Fung, M. K., 2006. Scale economies, X-efficiency and convergence of productivity among bank holding companies. Journal of Banking \& Finance, 30, 2857-2874.

Gilbert, R. A., Wilson, P.W., 1998. Effects of deregulation on the productivity of Korean banks, Journal of Economics and Business, 50, 133-155.

Giraleas D., Emrouznejad, A., Thanassoulis E., 2012. Productivity change using growth accounting and frontier-based approaches: Evidence from a Monte Carlo analysis. European Journal of Operational Research, 222, 673-683.

Goddard, J.A., Liu, H., Molyneux, P., Wilson, J.O.S., 2013. Do bank profits converge? European Financial Management, 19, 345-65

Goddard, J.A., Molyneux, P., Wilson, J.O.S., Tavakoli, M., 2007. European banking: An overview. Journal of Banking \& Finance, 31, 1911-35.

Goddard, J., Molyneux, P., Wilson, J.O.S., 2010. Banking in the European Union. In: Berger, A.N., Molyneux, P., Wilson, J.O.S., (eds.) Oxford Handbook of Banking. Oxford University Press, Oxford. 
Goddard, J., Molyneux, P., Wilson, J.O.S., 2015. Banking in the European Union: Deregulation, Crisis and Renewal. In: Berger, A.N., Molyneux, P., Wilson, J.O.S. (eds.) Oxford Handbook of Banking, $2^{\text {nd }}$ edition. Oxford University Press, Oxford.

Grifell-Tatje, E., Lovell, C.A.K., 1996. Deregulation and productivity decline: The case of Spanish saving banks. European Economic Review, 40, 1281-1303.

Hadri, K., 2000. Testing for stationarity in heterogeneous panel data. Econometrics Journal, 3, $148-161$.

Horta I. M., Camanho A.S., 2015. A non-parametric methodology for evaluating convergence in a multi-input, multi-output setting. European Journal of Operational Research, 246, $554-561$.

Hughes J., Mester L., 2015. Measuring the performance of banks: theory, practice, evidence, and some policy implications. In Berger, A.N., P. Molyneux and J.O.S. Wilson (eds.) Oxford Handbook of Banking, $2^{\text {nd }}$ Edition Oxford University Press, Oxford.

Humphrey, D.B., 1992. Flow versus stock indicators of banking output: Effects on productivity and scale economy measurement. Journal of Financial Services Research, 6, 115-135.

Hulten, C.R., Dean, E.R., Harper, M.J., (eds.) 2001. New Developments in Productivity Analysis. University of Chicago Press, Chicago.

Isik, I., Hassan, K., 2003. Financial deregulation and total factor productivity change: An empirical study of Turkish commercial banks. Journal of Banking \& Finance, 27, 14551485.

Islam, N., 2003. What have we learned from the convergence debate? Journal of Economic Surveys, 17, 309-362.

Kashyap, A.K., Stein, J.C., 2000. What do a million observations on banks say about the transmission of monetary policy? American Economic Review, 90, 407-428. 
Kerstens, K., Van de Woestyne, I., 2014. Comparing Malmquist and Hicks-Moorsteen productivity indices: Exploring the impact of unbalanced vs. balanced panel data. European Journal of Operational Research, 233, 749-758

Kontolaimou, A. and Tsekouras, K., 2010. Are cooperatives the weakest link in European banking? A non-parametric meta-frontier approach. Journal of Banking \& Finance, 34, $1946-1957$.

Kontolaimou, A., Kounetas, K., Mourtos, I., Tsekouras, K., 2012. Technology gaps in European banking: Put the blame on inputs or outputs? Economic Modelling, 29, 17981808.

Kounetas, K., Mourtos, I. and Tsekouras, K., 2009. Efficiency decompositions for heterogeneous technologies. European Journal of Operational Research, 199, 209-218.

Kumbhakar, S.C., Lovell, C.A.K., 2000. Stochastic Frontier Analysis. Cambridge University Press, New York.

Kumbhakar, Subal C., Lozano-Vivas, A., Lovell, C.A.K., Iftekhar, H., 2001. The effects of deregulation on the performance of financial institutions: The case of Spanish savings banks, Journal of Money, Credit and Banking, 33, 101-120.

Leightner, J.E., Lovell, C.A.K., 1998. The impact of financial liberalization on the performance of Thai banks. Journal of Economics and Business, 50, 115-131

Levin, A., Lin, C.F., Chu, C.S.J., 2002. Unit root tests in panel data: asymptotic and finitesample properties. Journal of Econometrics, 108, 1-24.

Lichtenberg, F.R., 1994. Testing the convergence hypothesis. Review of Economics and Statistics, 76, 576-579.

Lozano-Vivas, A., 1997. Profit efficiency for Spanish savings banks. European Journal of Operational Research, 98, 381-394. 
Malmquist, S., 1953. Index numbers and indifference surfaces. Trabajos de Estatistica, 4, 209242.

Meeusen W., Van den Broek, J., 1977. Efficiency estimations from Cobb-Douglas production functions with composed error. International Economic Review, 18, 435-444.

Mendes, V., Rebelo, J., 1999. Productive efficiency, technological change and productivity in Portuguese banking, Applied Financial Economics, 9, 513-521.

O’Donnell, C.J., Rao, D.S.P., Battese, G.E., 2008. Meta-frontier frameworks for the study of firm-level efficiencies and technology ratios. Empirical Economics, 34, 231-255.

Sealey, G. W., Lindley, J.T., 1977. Inputs, outputs and a theory of production and cost at depository financial institutions. Journal of Finance, 32, 1251-1266.

Stiroh, Kevin J., 2000. How did bank holding companies prosper in the 1990s? Journal of Banking \& Finance, 24, 1703-1745.

Sturm, J.E., Williams, B., 2004. Foreign bank entry, deregulation and bank efficiency: Lessons from the Australian experience. Journal of Banking \& Finance, 28, 1775-1799.

Thanassoulis E, Shiraz, R.K., Maniadakis, N. 2015. A cost Malmquist productivity index capturing group performance. European Journal of Operational Research, 241, 796-805.

Tirtiroglu, D., Daniels, K.N., Tirtigoglu, E., 2005. Deregulation, intensity of competition, industry evolution, and the productivity growth of U.S. commercial banks. Journal of Money, Credit and Banking, 37, 339-360.

Wheelock, D. C., Wilson, P.W., 1999. Technical progress, inefficiency, and productivity change in US banking, 1984 -1993, Journal of Money, Credit, and Banking, 31, 212234. 
Table 1

Aggregate Balance Sheet Information for Commercial Banks (averages)

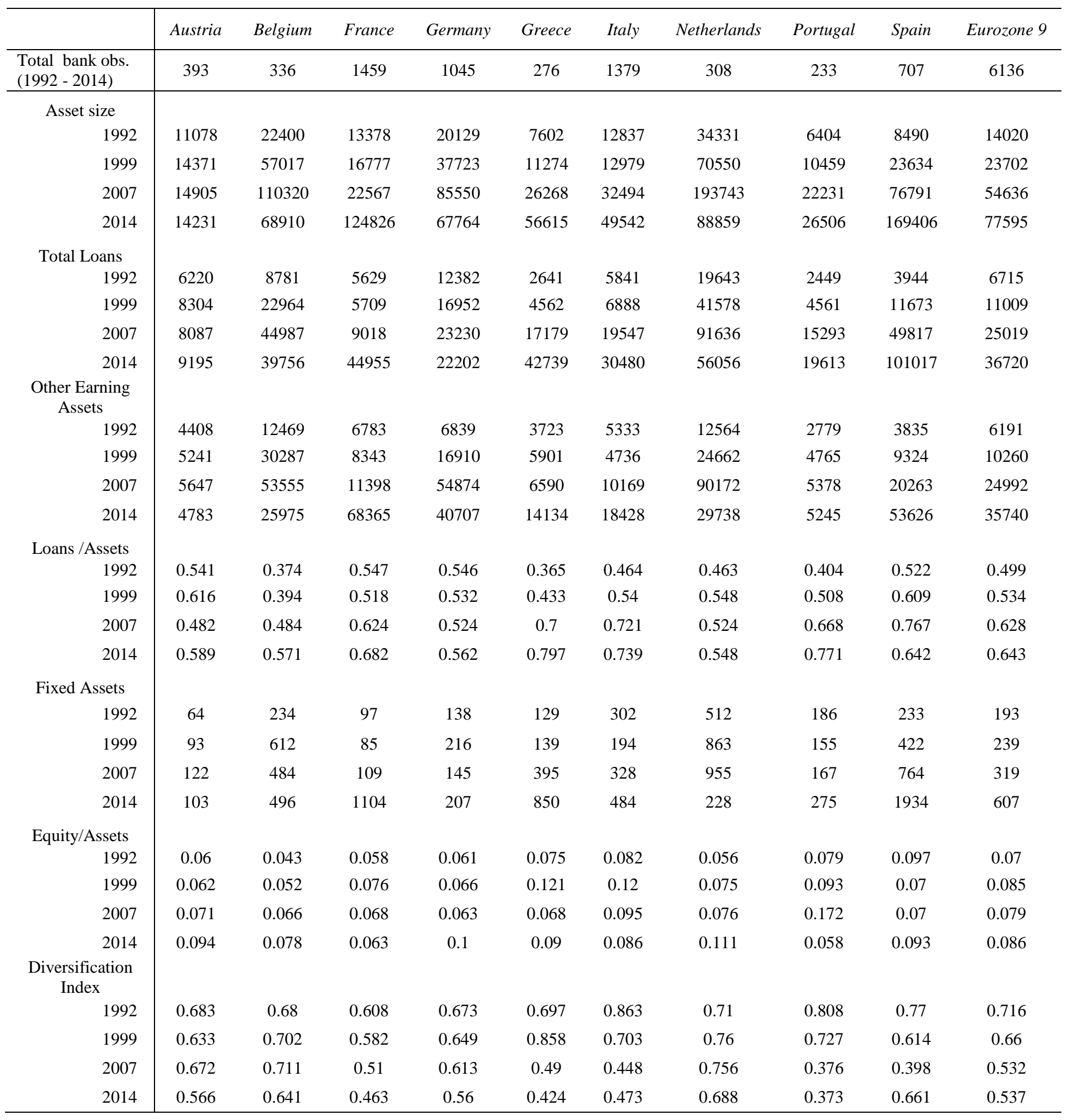

Note: The Table presents descriptive statistics (average values) for all banks in our sample at the beginning of the sample period (1992); at the introduction of the single currency (1999); at the start of the financial crisis (2007); and at the end of the sample period (2014). Values are in euro million. All data are deflated using 2005 as the base year. 
Table 2

Main results from the country-specific stochastic frontiers, 1992-2014

\begin{tabular}{|c|c|c|c|c|c|c|c|c|c|}
\hline & Austria & Belgium & France & Germany & Greece & Italy & Netherlands & Portugal & Spain \\
\hline \multicolumn{10}{|l|}{ ey1 } \\
\hline $92-14$ & 0.556 & 0.462 & 0.583 & 0.522 & 0.542 & 0.615 & 0.447 & 0.537 & 0.601 \\
\hline pre 99 & 0.584 & 0.391 & 0.552 & 0.480 & 0.477 & 0.500 & 0.467 & 0.444 & 0.533 \\
\hline $99-07$ & 0.556 & 0.463 & 0.592 & 0.546 & 0.577 & 0.627 & 0.427 & 0.587 & 0.669 \\
\hline post 07 & 0.537 & 0.565 & 0.637 & 0.541 & 0.695 & 0.737 & 0.460 & 0.687 & 0.648 \\
\hline \multicolumn{10}{|l|}{ ey2 } \\
\hline $92-14$ & 0.417 & 0.531 & 0.397 & 0.447 & 0.429 & 0.386 & 0.523 & 0.455 & 0.375 \\
\hline pre 99 & 0.405 & 0.609 & 0.430 & 0.490 & 0.493 & 0.506 & 0.517 & 0.532 & 0.452 \\
\hline $99-07$ & 0.416 & 0.534 & 0.397 & 0.426 & 0.393 & 0.374 & 0.506 & 0.400 & 0.301 \\
\hline post 07 & 0.427 & 0.412 & 0.323 & 0.423 & 0.285 & 0.258 & 0.491 & 0.352 & 0.319 \\
\hline \multicolumn{10}{|l|}{ ey3 } \\
\hline $92-14$ & 0.533 & 0.626 & 0.499 & 0.534 & 0.607 & 0.363 & 0.713 & 0.547 & 0.536 \\
\hline pre 99 & 0.615 & 0.720 & 0.567 & 0.585 & 0.740 & 0.470 & 0.717 & 0.694 & 0.602 \\
\hline $99-07$ & 0.522 & 0.602 & 0.449 & 0.536 & 0.495 & 0.307 & 0.712 & 0.509 & 0.481 \\
\hline post 07 & 0.489 & 0.518 & 0.430 & 0.473 & 0.494 & 0.305 & 0.684 & 0.252 & 0.468 \\
\hline \multicolumn{10}{|l|}{ ew2 } \\
\hline $92-14$ & 0.467 & 0.374 & 0.501 & 0.466 & 0.393 & 0.637 & 0.287 & 0.453 & 0.464 \\
\hline pre 99 & 0.385 & 0.280 & 0.433 & 0.415 & 0.260 & 0.530 & 0.283 & 0.306 & 0.398 \\
\hline $99-07$ & 0.478 & 0.398 & 0.551 & 0.464 & 0.505 & 0.693 & 0.288 & 0.491 & 0.519 \\
\hline post 07 & 0.511 & 0.482 & 0.570 & 0.527 & 0.506 & 0.695 & 0.316 & 0.748 & 0.532 \\
\hline \multicolumn{10}{|l|}{$\mathrm{EFF}$} \\
\hline $92-14$ & 0.935 & 0.985 & 0.972 & 0.959 & 0.957 & 0.96 & 0.961 & 0.947 & 0.967 \\
\hline pre 99 & 0.938 & 0.985 & 0.971 & 0.961 & 0.954 & 0.956 & 0.965 & 0.956 & 0.972 \\
\hline 99-07 & 0.937 & 0.985 & 0.973 & 0.963 & 0.959 & 0.963 & 0.959 & 0.944 & 0.967 \\
\hline post 07 & 0.930 & 0.983 & 0.973 & 0.952 & 0.957 & 0.963 & 0.954 & 0.931 & 0.954 \\
\hline \multirow[t]{2}{*}{ EUR } & 0.055 & -0.081 & -0.068 & -0.020 & -0.019 & -0.045 & 0.094 & 0.177 & 0.070 \\
\hline & $(0.25)$ & $(0.00)$ & $(0.00)$ & $(0.00)$ & $(0.52)$ & $(0.00)$ & $(0.08)$ & $(0.74)$ & $(0.04)$ \\
\hline \multirow[t]{2}{*}{ D07 } & -0.028 & 0.062 & 0.176 & -0.002 & -0.013 & 0.108 & 0.134 & 0.006 & 0.071 \\
\hline & $(0.44)$ & $(0.44)$ & $(0.00)$ & (0.99) & $(0.94)$ & $(0.00)$ & $(0.12)$ & $(0.94)$ & $(0.00)$ \\
\hline \multirow[t]{2}{*}{ Div index } & -0.067 & -0.078 & -0.132 & -0.170 & -0.063 & -0.086 & -0.118 & -0.046 & -0.119 \\
\hline & $(0.04)$ & $(0.00)$ & $(0.00)$ & $(0.00)$ & $(0.20)$ & $(0.00)$ & $(0.01)$ & $(0.31)$ & $(0.00)$ \\
\hline \multirow[t]{2}{*}{ Equity/Assets } & -0.548 & -0.550 & -0.607 & -0.549 & -0.414 & -0.341 & -0.992 & -0.494 & -0.509 \\
\hline & $(0.00)$ & $(0.00)$ & $(0.00)$ & $(0.00)$ & $(0.01)$ & $(0.00)$ & $(0.00)$ & $(0.00)$ & $(0.00)$ \\
\hline \multirow[t]{2}{*}{ Fixed assets } & 0.010 & 0.000 & 0.012 & 0.016 & 0.007 & 0.004 & 0.005 & 0.032 & 0.014 \\
\hline & $(0.01)$ & $(0.99)$ & $(0.00)$ & $(0.00)$ & $(0.44)$ & $(0.05)$ & $(0.30)$ & $(0.00)$ & $(0.00)$ \\
\hline
\end{tabular}

Note: The Table reports the main summary results from the estimation of Equation (1) for each country in the sample. The following results are reported; ey $1=$ elasticity of costs with respect to loans; ey $2=$ elasticity of costs with respect to other earning assets; ew $1=$ elasticity of costs with respect to deposits; ew2= elasticity of costs with respect to personnel, capital and other administrative expenses; EFF = average efficiency score; $\mathrm{EUR}=$ the coefficient of the Euro intercept dummy variable; D07 = dummy for the financial crisis; the p-values for EUR and D07 reflect the test of joint significance that includes also the interactive terms. Div. index $=$ diversification index; Equity/assets = capital to assets ratio (a proxy of risk); Fixed assets $=$ a proxy of size. The p-values are reported in parentheses. 
Table 3

Country- Level Divisia Indices: Total Factor Productivity Change and its Components

\begin{tabular}{|c|c|c|c|c|c|c|c|}
\hline Countries & Years & $T F P^{k}$ & $S C^{k}$ & $T C^{k}$ & $E X^{k}$ & $A L L C^{k}$ & $E C^{k}$ \\
\hline \multirow{4}{*}{ Austria } & 1992-2014 & 1.001 & 1.001 & 1.010 & 0.990 & 0.999 & 1.002 \\
\hline & 1992-1998 & 1.004 & 1.000 & 1.017 & 0.986 & 0.997 & 1.003 \\
\hline & 1999-2006 & 1.002 & 1.002 & 1.010 & 0.988 & 1.001 & 1.000 \\
\hline & $2007-2014$ & 0.999 & 1.000 & 1.004 & 0.995 & 0.997 & 1.002 \\
\hline \multirow[t]{4}{*}{ Belgium } & $1992-2014$ & 1.004 & 1.000 & 1.008 & 0.998 & 0.998 & 1.000 \\
\hline & $1992-1998$ & 1.000 & 1.000 & 1.006 & 0.996 & 0.999 & 1.000 \\
\hline & 1999-2006 & 1.004 & 1.000 & 1.008 & 0.995 & 1.000 & 1.000 \\
\hline & $2007-2014$ & 1.006 & 0.999 & 1.010 & 1.002 & 0.994 & 1.000 \\
\hline \multirow[t]{4}{*}{ France } & $1992-2014$ & 1.004 & 1.001 & 1.007 & 0.996 & 1.001 & 1.000 \\
\hline & $1992-1998$ & 1.002 & 1.000 & 1.008 & 0.995 & 0.999 & 0.999 \\
\hline & 1999-2006 & 1.001 & 1.001 & 1.007 & 0.994 & 1.000 & 1.000 \\
\hline & $2007-2014$ & 1.009 & 1.002 & 1.006 & 0.999 & 1.002 & 1.000 \\
\hline \multirow[t]{4}{*}{ Germany } & $1992-2014$ & 1.003 & 1.001 & 1.001 & 1.002 & 0.999 & 1.000 \\
\hline & $1992-1998$ & 1.006 & 1.001 & 1.006 & 1.004 & 0.995 & 1.000 \\
\hline & 1999-2006 & 1.003 & 1.001 & 1.002 & 1.001 & 1.000 & 1.000 \\
\hline & $2007-2014$ & 1.000 & 1.000 & 0.998 & 1.001 & 1.002 & 0.999 \\
\hline \multirow[t]{4}{*}{ Greece } & $1992-2014$ & 1.005 & 1.004 & 1.002 & 0.994 & 1.003 & 1.001 \\
\hline & 1992-1998 & 1.004 & 1.002 & 0.993 & 1.006 & 1.002 & 1.002 \\
\hline & $1999-2006$ & 1.003 & 1.006 & 1.003 & 0.990 & 1.004 & 1.001 \\
\hline & 2007-2009 & 1.011 & 1.003 & 1.021 & 0.984 & 1.001 & 1.002 \\
\hline \multirow[t]{4}{*}{ Italy } & $1992-2014$ & 1.011 & 1.000 & 1.018 & 0.994 & 0.997 & 1.002 \\
\hline & $1992-1998$ & 1.025 & 1.000 & 1.035 & 0.992 & 0.994 & 1.005 \\
\hline & 1999-2006 & 1.002 & 1.000 & 1.018 & 0.985 & 0.999 & 1.000 \\
\hline & $2007-2014$ & 1.010 & 1.000 & 1.006 & 1.006 & 0.996 & 1.001 \\
\hline \multirow[t]{4}{*}{ Netherlands } & $1992-2014$ & 1.002 & 1.002 & 1.001 & 1.000 & 0.999 & 1.000 \\
\hline & $1992-1998$ & 1.004 & 1.002 & 1.003 & 1.000 & 0.999 & 1.000 \\
\hline & 1999-2006 & 1.000 & 1.004 & 1.001 & 0.994 & 0.999 & 1.002 \\
\hline & $2007-2014$ & 1.002 & 1.000 & 0.999 & 1.005 & 0.999 & 0.999 \\
\hline \multirow[t]{4}{*}{ Portugal } & $1992-2014$ & 1.017 & 1.005 & 1.018 & 0.992 & 1.002 & 1.000 \\
\hline & $1992-1998$ & 1.012 & 1.002 & 1.014 & 0.996 & 1.000 & 1.000 \\
\hline & 1999-2006 & 1.012 & 1.007 & 1.017 & 0.979 & 1.006 & 1.002 \\
\hline & $2007-2014$ & 1.026 & 1.005 & 1.021 & 1.003 & 0.999 & 0.997 \\
\hline \multirow[t]{4}{*}{ Spain } & $1992-2014$ & 1.007 & 1.002 & 1.010 & 0.999 & 0.996 & 0.999 \\
\hline & 1992-1998 & 0.995 & 1.001 & 1.006 & 0.993 & 0.997 & 0.997 \\
\hline & 1999-2006 & 1.007 & 1.003 & 1.008 & 0.995 & 1.001 & 0.999 \\
\hline & $2007-2014$ & 1.017 & 1.001 & 1.015 & 1.008 & 0.991 & 1.001 \\
\hline
\end{tabular}

Note: The Table reports the results of the estimation of the Divisia indices of Total Factor Productivity (TFP) change at the single-country level (indicated by the superscript $k$ ). The Divisia index is computed using Equation (2), which in turn uses the coefficients derived from the estimation of the translog Stochastic Frontiers specified in Equation (1). In the Table, TFPk is decomposed into five components: scale efficiency change $\left(\mathrm{SC}^{\mathrm{k}}\right)$; technical change $\left(\mathrm{TC}^{\mathrm{k}}\right)$; changes due to environmental factors $\left(\mathrm{EX}^{\mathrm{k}}\right)$; changes in allocative efficiency $\left(\mathrm{ALLC}^{\mathrm{k}}\right)$; changes in cost efficiency $\left(\mathrm{EC}^{\mathrm{k}}\right)$. For presentational purposes the original positive and negative growth rate values of the Divisia index have been transformed into growth values respectively larger or smaller than 1. Values larger than 1 indicate increases in productivity; values smaller than 1 indicate decreases in productivity. Greek banks are excluded from the sample post 2009. 
Table 4

Meta-frontier Divisia Index: Total Factor Productivity Change and its Components

\begin{tabular}{|c|c|c|c|c|c|c|c|}
\hline Countries & Years & $T F P^{*}$ & $S C^{*}$ & $T C^{*}$ & $E X^{*}$ & $A L L C^{*}$ & $E C^{*}$ \\
\hline \multirow[t]{4}{*}{ Austria } & 1992-2014 & 1.009 & 0.999 & 1.019 & 1.001 & 0.998 & 0.995 \\
\hline & 1992-1998 & 1.003 & 1.000 & 1.010 & 0.999 & 0.998 & 0.995 \\
\hline & 1999-2006 & 1.016 & 0.998 & 1.019 & 1.002 & 1.010 & 0.987 \\
\hline & $2007-2014$ & 1.006 & 0.999 & 1.026 & 1.000 & 0.975 & 1.005 \\
\hline \multirow[t]{4}{*}{ Belgium } & 1992-2014 & 1.006 & 1.000 & 1.016 & 1.001 & 0.998 & 1.001 \\
\hline & $1992-1998$ & 1.001 & 1.000 & 1.010 & 1.000 & 0.995 & 0.996 \\
\hline & 1999-2006 & 1.016 & 0.999 & 1.014 & 1.002 & 1.004 & 0.996 \\
\hline & $2007-2014$ & 0.997 & 1.001 & 1.024 & 1.001 & 0.961 & 1.010 \\
\hline \multirow[t]{4}{*}{ France } & 1992-2014 & 1.007 & 1.001 & 1.008 & 1.001 & 0.999 & 0.999 \\
\hline & 1992-1998 & 1.005 & 1.000 & 1.004 & 1.002 & 1.003 & 0.996 \\
\hline & 1999-2006 & 1.008 & 1.001 & 1.006 & 1.001 & 1.006 & 0.994 \\
\hline & $2007-2014$ & 1.008 & 1.001 & 1.014 & 0.999 & 0.985 & 1.009 \\
\hline \multirow[t]{4}{*}{ Germany } & 1992-2014 & 1.002 & 0.999 & 1.016 & 1.001 & 0.988 & 0.997 \\
\hline & $1992-1998$ & 1.000 & 1.000 & 1.009 & 1.001 & 0.993 & 0.996 \\
\hline & 1999-2006 & 1.009 & 1.000 & 1.016 & 1.001 & 1.001 & 0.992 \\
\hline & 2007-2014 & 0.995 & 0.999 & 1.023 & 1.002 & 0.966 & 1.005 \\
\hline \multirow[t]{4}{*}{ Greece } & 1992-2014 & 1.004 & 0.999 & 1.012 & 0.996 & 0.996 & 1.001 \\
\hline & 1992-1998 & 0.998 & 1.001 & 1.008 & 1.002 & 0.993 & 0.993 \\
\hline & 1999-2006 & 1.012 & 0.997 & 1.012 & 0.992 & 1.001 & 1.010 \\
\hline & 2007-2009 & 0.987 & 1.000 & 1.025 & 0.999 & 0.982 & 0.982 \\
\hline \multirow[t]{4}{*}{ Italy } & 1992-2014 & 1.008 & 1.000 & 1.006 & 0.997 & 1.002 & 1.003 \\
\hline & $1992-1998$ & 1.018 & 1.000 & 0.999 & 1.000 & 1.001 & 1.017 \\
\hline & 1999-2006 & 1.004 & 1.000 & 0.999 & 0.994 & 1.013 & 0.998 \\
\hline & $2007-2014$ & 1.004 & 0.999 & 1.023 & 0.998 & 0.987 & 0.997 \\
\hline \multirow[t]{4}{*}{ Netherlands } & 1992-2014 & 1.013 & 0.996 & 1.034 & 1.002 & 0.991 & 0.990 \\
\hline & 1992-1998 & 1.010 & 0.997 & 1.017 & 1.002 & 1.003 & 0.991 \\
\hline & 1999-2006 & 1.029 & 0.992 & 1.038 & 1.003 & 1.015 & 0.981 \\
\hline & 2007-2014 & 0.996 & 0.999 & 1.044 & 1.001 & 0.950 & 1.002 \\
\hline \multirow[t]{4}{*}{ Portugal } & 1992-2014 & 1.035 & 1.002 & 1.029 & 0.999 & 1.004 & 1.000 \\
\hline & $1992-1998$ & 1.007 & 1.000 & 1.007 & 0.998 & 0.988 & 1.014 \\
\hline & 1999-2006 & 1.034 & 0.999 & 1.027 & 0.997 & 1.015 & 0.997 \\
\hline & 2007-2014 & 1.061 & 1.010 & 1.050 & 1.003 & 1.005 & 0.992 \\
\hline \multirow[t]{4}{*}{ Spain } & 1992-2014 & 1.011 & 1.000 & 1.014 & 1.000 & 0.999 & 0.998 \\
\hline & 1992-1998 & 0.993 & 1.000 & 1.003 & 0.997 & 0.995 & 0.997 \\
\hline & 1999-2006 & 1.021 & 1.000 & 1.010 & 0.998 & 1.021 & 0.992 \\
\hline & $2007-2014$ & 1.012 & 0.999 & 1.027 & 1.005 & 0.974 & 1.007 \\
\hline
\end{tabular}

Note: The Table reports the results of the estimation of the Divisia indices of Total Factor Productivity (TFP*) change at the Eurozone level. The Divisia index is computed using Equation (2), which in turn uses the coefficients derived from the estimation of the meta-frontier (indicated by the superscript*) using Equations (4) and (5). TFP change is decomposed into its five components: scale efficiency change ( $\left.\mathrm{SC}^{*}\right)$; technical change $\left(\mathrm{TC}^{*}\right)$; changes due to environmental factors $(\mathrm{EX} *)$; changes in allocative efficiency (ALLC*); changes in cost efficiency (EC*). For presentational purposes the original positive and negative growth rate values of the Divisia index have been transformed into growth values respectively larger or smaller than 1. Values larger than 1 indicate increases in productivity; values smaller than 1 indicate decreases in productivity. Greek banks are excluded from the sample post 2009. 
Table 5

Technological Gap Ratios, Cost Efficiency and Meta-efficiency

\begin{tabular}{|c|c|c|c|c|}
\hline & & $T G R$ & Cost efficiency & Meta-efficiency \\
\hline \multirow[t]{4}{*}{ Austria } & 1992-2014 & 0.831 & 0.935 & 0.779 \\
\hline & $1992-1998$ & 0.947 & 0.938 & 0.890 \\
\hline & 1999-2006 & 0.825 & 0.937 & 0.776 \\
\hline & $2007-2014$ & 0.759 & 0.930 & 0.709 \\
\hline \multirow[t]{4}{*}{ Belgium } & 1992-2014 & 0.755 & 0.985 & 0.743 \\
\hline & 1992-1998 & 0.794 & 0.985 & 0.782 \\
\hline & 1999-2006 & 0.734 & 0.985 & 0.723 \\
\hline & 2007-2014 & 0.722 & 0.983 & 0.710 \\
\hline \multirow[t]{4}{*}{ France } & 1992-2014 & 0.822 & 0.972 & 0.799 \\
\hline & $1992-1998$ & 0.833 & 0.971 & 0.809 \\
\hline & 1999-2006 & 0.797 & 0.973 & 0.776 \\
\hline & 2007-2014 & 0.840 & 0.973 & 0.817 \\
\hline \multirow[t]{4}{*}{ Germany } & 1992-2014 & 0.817 & 0.959 & 0.784 \\
\hline & 1992-1998 & 0.862 & 0.961 & 0.828 \\
\hline & 1999-2006 & 0.802 & 0.958 & 0.773 \\
\hline & $2007-2014$ & 0.784 & 0.952 & 0.747 \\
\hline \multirow[t]{4}{*}{ Greece } & 1992-2014 & 0.836 & 0.957 & 0.800 \\
\hline & 1992-1998 & 0.837 & 0.957 & 0.799 \\
\hline & 1999-2006 & 0.842 & 0.959 & 0.808 \\
\hline & 2007-2009 & 0.798 & 0.957 & 0.764 \\
\hline \multirow[t]{4}{*}{ Italy } & 1992-2014 & 0.919 & 0.960 & 0.883 \\
\hline & 1992-1998 & 0.908 & 0.956 & 0.868 \\
\hline & 1999-2006 & 0.932 & 0.963 & 0.898 \\
\hline & 2007-2014 & 0.917 & 0.963 & 0.883 \\
\hline \multirow[t]{4}{*}{ Netherlands } & 1992-2014 & 0.674 & 0.961 & 0.648 \\
\hline & $1992-1998$ & 0.772 & 0.965 & 0.745 \\
\hline & 1999-2006 & 0.624 & 0.959 & 0.599 \\
\hline & 2007-2014 & 0.610 & 0.954 & 0.583 \\
\hline \multirow[t]{4}{*}{ Portugal } & 1992-2014 & 0.833 & 0.947 & 0.789 \\
\hline & $1992-1998$ & 0.846 & 0.956 & 0.809 \\
\hline & 1999-2006 & 0.820 & 0.944 & 0.773 \\
\hline & $2007-2014$ & 0.819 & 0.931 & 0.763 \\
\hline \multirow[t]{4}{*}{ Spain } & 1992-2014 & 0.842 & 0.967 & 0.814 \\
\hline & $1992-1998$ & 0.856 & 0.972 & 0.832 \\
\hline & $1999-2006$ & 0.834 & 0.967 & 0.807 \\
\hline & $2007-2014$ & 0.821 & 0.954 & 0.784 \\
\hline
\end{tabular}

Note: The Table reports the results of the estimation of the meta-frontier for every country over the entire sample period (19922009) as well as in two sub-periods (before and after the introduction of the common currency). Results are presented for the following scores: the Technological Gap Ratio (TGR), the cost efficiency level and the meta-efficiency score. Recall that the TGR measures the distance between the country specific frontier and the meta-frontier, with values closer to 1 indicating a closer proximity between the two and vice versa. The cost efficiency level is the distance of banks from their country-specific frontier and measures how efficiently banks perform their operations using their country-specific technology but not necessarily the best available technology. The meta-efficiency score is the product of the two and measures the distance from the metafrontier. Greek banks are excluded from the sample post 2009. 
Table 6

Proportion of Technology Leaders in Each Country

\begin{tabular}{l|cc}
\hline & $\mathbf{1 9 9 2 - 1 9 9 8}$ & $\mathbf{1 9 9 9 - 2 0 1 4}$ \\
\hline Austria & 0.35 & 0.00 \\
Belgium & 0.00 & 0.00 \\
France & 0.00 & 0.035 \\
Germany & 0.16 & 0.05 \\
Greece & 0.00 & 0.00 \\
Netherlands & 0.006 & 0.005 \\
Italy & 0.48 & 0.88 \\
Portugal & 0.017 & 0.007 \\
Spain & 0.00 & 0.005 \\
Proportion of technology leaders & $7.2 \%$ & $11.6 \%$ \\
Total number of technology leaders & 172 & 431 \\
Total number of banks & 2394 & 3700 \\
\hline Spearman rank correlation coefficient (p-value) & \multicolumn{2}{|c}{$0.58(0.00)$} \\
Bonett-Wright correlation confidence interval: 95\% & \multicolumn{2}{c}{$0.53-0.78$} \\
Bonett-Wright correlation confidence interval: 99\% & $0.49-0.82$ \\
\hline
\end{tabular}

Note: The upper panel of the table reports the proportion of "technology leaders" in each country derived from the estimation of the meta-frontier. A technology leader is defined as a bank with a TGR value $>0.95$. A technology leader is therefore a bank that adopts the best technology and contributes to the progress of the meta-frontier at the eurozone level.

The lower panel of the table reports the results of correlations tests to compare the full, bank-level TGR rankings (not just the country averages) before and after the introduction of the common currency. The Spearman rank correlation coefficient (with p-value into brackets) tests that the TGR rankings before and after the introduction of the single currency are totally independent. The Bonett-Wright is a confidence interval for the correlation coefficient. The tests indicate that while not entirely independent, the rankings have certainly not remained the same and a degree of re-shuffling before and after the introduction of the common currency has taken place. 
Table 7

Catch-up indices of technological change

\begin{tabular}{|c|c|c|c|c|c|}
\hline & $\begin{array}{c}1992-1998 \\
\text { (a) }\end{array}$ & $\begin{array}{c}1999-2007 \\
\text { (b) }\end{array}$ & $\begin{array}{l}\text { Change } \\
\text { (a) to (b) }\end{array}$ & $\begin{array}{c}1999-2014 \\
\text { (c) }\end{array}$ & $\begin{array}{l}\text { Change } \\
\text { (a) to (c) }\end{array}$ \\
\hline Austria & 0.995 & 1.010 & $\uparrow$ & 1.016 & $\uparrow$ \\
\hline Belgium & 1.004 & 1.007 & $\uparrow$ & 1.010 & $\uparrow$ \\
\hline France & 0.996 & 1.000 & $\uparrow$ & 1.004 & $\uparrow$ \\
\hline Germany & 1.004 & 1.016 & $\uparrow$ & 1.020 & $\uparrow$ \\
\hline Greece & 1.016 & 1.006 & $\downarrow$ & 1.006 & $\downarrow$ \\
\hline Italy & 0.966 & 0.983 & $\uparrow$ & 0.999 & $\uparrow$ \\
\hline Netherlands & 1.015 & 1.038 & $\uparrow$ & 1.042 & $\uparrow$ \\
\hline Portugal & 0.994 & 1.010 & $\uparrow$ & 1.019 & $\uparrow$ \\
\hline Spain & 0.995 & 1.003 & $\uparrow$ & 1.007 & $\uparrow$ \\
\hline
\end{tabular}

Note: The Catch Up index measures the speed of convergence of national frontiers toward the meta-frontier. It is computed as the ratio of the technical change of the meta-frontier to that of the national frontier between two points in time. An increase of the index over time implies a reduction in the speed of catch-up, and vice versa. 
Table 8

Panel unit root tests for convergence

\begin{tabular}{|c|c|c|c|}
\hline Test & Specification & Statistic & p-value \\
\hline Levin Lin Chu & 1 lag, no time trend & Adj t*: -1.63 & 0.052 \\
\hline Fisher-type; & $1 \mathrm{lag}$, panel no time trend & Inv. $X^{2} P$ : & 0.0002 \\
\hline & & Inv. Norm Z: $\quad-3.6992$ & 0.0001 \\
\hline & & Inv. Logit L*: $\quad-3.7716$ & 0.0002 \\
\hline & & Mod. Inv $X^{2}: 4.9087$ & 0.0000 \\
\hline Hadri LM & No time trend, het. Robust & Z: 19.3918 & 0.0000 \\
\hline
\end{tabular}

Note: The null hypothesis in the Levin-Lin-Chu test is non-stationarity. The alternative is that all the series are stationary and share the same autoregressive coefficient. We find stationarity and hence convergence with a level of significance of 5.2\% The Fisher type test consists of a combination of the p-values obtained from separate unit root tests performed on each of the panels. Following Choi (2001) this is performed using four methods, two based on an inverse $\chi^{2}$ (the second one valid if $\mathrm{N}$ goes to infinity, so less relevant here), one on an inverse normal, and one on an inverse logit. The null in Fisher-type test is again of non-stationarity but the alternative allows for stationarity with different autoregressive coefficients. This time we find stationarity and hence convergence at much higher level of significance than in the LLC test, as expected since the alternative is more flexible.

Finally the Hadri LM test (2000) tests for the hypothesis that all series are (trend) stationary against the alternative that at least one has a unit root. We reject the null and conclude that at least one of the series has a unit root (i.e. convergence is taking place, but not across all countries or in the same way). The inference remains the same under different specifications regarding the existence of a time trend. 
Table 9

ADF unit root test of convergence

\begin{tabular}{lcccc}
\hline & Lambda & p-value & Constant term & p-value \\
& $\lambda$ & & $\gamma$ & \\
& & & & \\
Austria & 0.69 & 0.04 & -0.002 & 0.11 \\
Belgium & 0.84 & 0.06 & -0.002 & 0.23 \\
France & 0.59 & 0.02 & -0.001 & 0.33 \\
Germany & 0.48 & 0.02 & -0.003 & 0.05 \\
Greece & 0.40 & 0.03 & -0.004 & 0.11 \\
Italy & 0.34 & 0.04 & 0.030 & 0.01 \\
Netherlands & 0.91 & 0.07 & -0.004 & 0.10 \\
Portugal & 0.65 & 0.90 & -0.001 & 0.57 \\
Spain & 0.61 & 0.04 & -0.001 & 0.45 \\
\hline
\end{tabular}

Note: The Table reports the results of the Augmented Dickey Fuller test (with one lagged difference term) for a unit root performed on Equation (11), which is estimated for each of the nine banking industries. The existence of a unit root, which is found if the coefficient $\lambda$ is not significant, indicates that there are no technical spillovers between the meta-frontier and the national frontier, therefore no convergence toward best technology. Convergence is found instead if $\lambda>0$, with full convergence given by a non-significant intercept $\gamma$.

We report directly the value of $\lambda$; the corresponding $\mathrm{p}$-value is the McKinnon p-value for $-\lambda$. The p-values for the intercept are based on the t-distribution. 
Table 10

Long Run and Short Run Tests for $\beta$ and $\sigma$-Convergence

\begin{tabular}{|c|c|c|}
\hline \multirow[t]{2}{*}{ Cost Efficiency } & Coefficient (p-value) & Coefficient (p-value) \\
\hline & Long Run & Short Run \\
\hline$\lambda$ & $-0.741(0.00)$ & $-0.332(0.00)$ \\
\hline$\gamma_{\mathrm{r}}$ & $<0(0.00)$ & $<0(0.00)$ \\
\hline $\mathrm{c}$ & $7.0(0.00)$ & \\
\hline \multicolumn{3}{|l|}{ Meta-efficiency } \\
\hline$\lambda$ & $-0.617(0.00)$ & $-0.084(0.00)$ \\
\hline$\gamma_{\mathrm{r}}$ & $<0(0.00)$ & $>0(0.00)$ \\
\hline $\mathrm{c}$ & $3.49(0.00)$ & \\
\hline \multicolumn{3}{|l|}{$T G R$} \\
\hline$\lambda$ & $-0.618(0.00)$ & $-0.08(0.00)$ \\
\hline$\gamma_{\mathrm{r}}$ & $<0(0.00)$ & $<0(0.00)$ \\
\hline $\mathrm{c}$ & $3.66(0.00)$ & \\
\hline
\end{tabular}

Note: The Table reports the results of the estimation of Equations (12), (13) and (15) for $\beta$ and $\sigma$ convergence. $\beta$ convergence is defined as a significant negative correlation between the initial values of the performance measure and its growth, and it is measured by a significantly negative coefficient $\lambda$. This is calculated both in the short run (year-by-year following the business cycle) and in the long run (as the difference in the performance at the beginning and at the end of the period of analysis). The possibility of conditional convergence is modelled by the introduction of country-specific dummy variables. Significant dummy coefficients $\gamma_{r}$ therefore indicate conditional convergence and thus different steady states of productivity among the countries. The estimated dummy coefficients are not reported individually but as a group for reasons of space. Finally for convergence to be present also $\sigma$ convergence must be found, which is defined as a significant reduction of the dispersion in performance levels between countries over time. This is measured by a non-significant $c$ statistic in the long run model, as defined in Equation (14). 